\title{
Serum uric acid levels as a risk stratification tool in hypertensive pregnancy
}

\section{Cimona Lyn Saldanha, Sabha Malik*, Azhar Un-Nisa Quraishi}

Department of Obstetrics and Gynecology, SKIMS Soura Srinagar, Jammu and Kashmir, India

Received: 25 September 2018

Accepted: 24 October 2018

\section{*Correspondence:}

Dr. Sabha Malik,

E-mail: mohdfida35@gmail.com

Copyright: () the author(s), publisher and licensee Medip Academy. This is an open-access article distributed under the terms of the Creative Commons Attribution Non-Commercial License, which permits unrestricted non-commercial use, distribution, and reproduction in any medium, provided the original work is properly cited.

\section{ABSTRACT}

Background: Hypertensive disorders represent the most common medical complication of pregnancy affecting between 7-15\% of all gestations and accounts for approximately a quarter of antenatal admissions.

Methods: A case-control study was conducted over a period of 1 year. A total of 200 subjects were enrolled in the study and were divided into two groups; 100 cases and 100 controls. Serum uric acid levels were measured in cases and controls. The serum uric acid levels were correlated with the severity of PIH and maternal and fetal complications.

Results: It was observed that the mean serum uric acid level in cases $(5.0 \pm 1.74 \mathrm{mg} / \mathrm{dl})$ was significantly higher compared to $2.66 \pm 0.39 \mathrm{mg} / \mathrm{dl}$ in controls. Serum uric acid levels also tended to increase with increasing severity of $\mathrm{PIH}$, increasing from $3.69 \pm 0.95 \mathrm{mg} / \mathrm{dl}$ in gestational hypertension to $6.36 \pm 1.38 \mathrm{mg} / \mathrm{dl}$ in severe PE. Maternal complications during antepartum and postpartum period were higher once $\mathrm{SUA} \geq 5 \mathrm{mg} / \mathrm{dl}$ was taken as a cut-off. Protienuria $(p=0.00)$, coagulopathy $(p=0.007)$, need for blood/platelet transfusion $(p=0.01)$ and eclampsia $(p=0.007)$ were significantly more. Similarly, complications were found to be higher, in babies born to mothers having serum uric acid more than $5 \mathrm{mg} / \mathrm{dl}$ compared to others in case group.

Conclusions: Higher serum uric acid levels may indicate higher risk of progression to preeclampsia and development of adverse maternal/infant conditions.

Keywords: Coagulopathy, Pre-eclampsia, Protienuria, Uric acid

\section{INTRODUCTION}

Hypertensive disorders represent the most common medical complication of pregnancy affecting between 7 $15 \%$ of all gestations and account for approximately a quarter of antenatal admissions. ${ }^{1}$ Hypertensive disorders during pregnancy can be included into four well-defined groups:

- Gestational hypertension

- $\quad$ Preeclampsia

- Chronic hypertension

- Preeclampsia superimposed on chronic hypertension.
Preeclampsia affects multiple organ systems and can lead to severe renal, hepatic, neurological and cardiopulmonary complications. Serum uric acid is a marker of oxidative stress, tissue injury and renal dysfunction, and therefore might be helpful in the prediction of complications of preeclampsia.

The role of uric acid in the pathophysiology of preeclampsia is not clear whether it is a marker of disease or it actively is involved in the pathogenesis of disease. ${ }^{2,3}$ Elevated uric acid concentrations were first noted in preeclamptic women in the late 1800 s. Since that time numerous reports have demonstrated a relationship between uric acid concentrations and severity of 
disease. $^{4,5}$ In uncomplicated pregnancies, serum uric acid concentrations fall in first trimester by $25-35 \% 6$ due to elevation in renal clearance secondary to increased glomerular filtration rate or reduced proximal tubular reabsorption; continue to remain low during second trimester and slowly increase during third trimester, possibly due to raised fetal production, decreased binding to albumin and a decline in uric acid clearance until towards end of pregnancy when they approach nonpregnant levels. ${ }^{6,7}$ In women with preeclampsia there is impaired trophoblastic invasion in the placenta and ischemic metabolite formation. ${ }^{8}$

These ischemic metabolites are responsible for peripheral vasoconstriction in gromeruli and glomerular endotheliosis results in decreased GFR and increased uric acid level..$^{9}$ The objective of the present study was to compare serum uric acid levels in normal pregnant and pregnancy induced hypertension $(\mathrm{PIH})$ women, and to correlate serum uric acid levels (SUA) with severity of $\mathrm{PIH}$ and maternal and fetal complications.

\section{METHODS}

A case control study was conducted in the Department of Obstetrics and Gynaecology, Sheri-Kashmir Institute of Medical Sciences, Soura, Srinagar from May 2017 to May 2018. The informed consent was obtained from all patients for being included in the study.

\section{Case Group}

Pregnant women with PIH with following criteria were included in the study:
- Gestational age $\geq 20$ weeks

- $\quad$ Blood pressure $\geq 140 / 90$.

\section{Exclusion criteria}

- Pregnant women with history of essential hypertension,

- Diabetes mellitus,

- Renal disorder,

- Liver disorder,

- Epilepsy,

- Urinary tract infection, and

- Gout.

\section{Control group}

This group included the healthy normotensive pregnant women between 20 and 40 weeks of gestation having similar demographic features as cases.

Serum uric acid levels were noted in cases and controls and the levels were compared between the two groups. The levels of uric acid were also compared with the severity of PIH and to the maternal and fetal complications developed later in pregnancy.

\section{RESULTS}

A total of 200 patients were examined, 100 being patients with PIH (case group) of varying severity and 100 normal pregnant women (control group). The age and parity in both groups were comparable. However, in case group, majority were nullipara (79\%). The level of serum uric acid $(\mathrm{mg} / \mathrm{dl})$ in both groups is shown in table 1 .

Table 1: Comparison of serum uric acid in cases and controls.

\begin{tabular}{|c|c|c|c|c|c|c|c|}
\hline & \multicolumn{2}{|c|}{ Cases $(n=100)$} & \multicolumn{3}{|c|}{ Controls $(\mathrm{n}=100)$} & \multirow[b]{2}{*}{ Min-Max } & \multirow[b]{2}{*}{$P$ value } \\
\hline \multirow{2}{*}{ Serum uric acid (mg/dl) } & Mean \pm SD & Median & Min-Max & Mean \pm SD & Median & & \\
\hline & $5.00 \pm 1.74$ & 4.80 & $2.1-8.1$ & $2.66 \pm 0.39$ & 2.60 & $2.1-3.6$ & $<0.001$ \\
\hline
\end{tabular}

Table 2: Correlation of serum uric acid with severity of PIH.

\begin{tabular}{|llllll|}
\hline & No. & Mean \pm SD & Median & Min-Max & P value \\
\hline Gestaional hypertension & 25 & $3.69 \pm 0.95$ & 3.600 & $2.1-5.6$ & $<0.001$ \\
\hline Mild preeclampsia & 28 & $4.85 \pm 1.09$ & 5.200 & $3.1-6.8$ & $3.1-8.1$ \\
\hline Severe preeclampsia & 47 & $6.36 \pm 1.38$ & 6.800 & 3 \\
\hline
\end{tabular}

The mean serum uric acid level of $5.0 \pm 1.74 \mathrm{mg} / \mathrm{dl}$ clearly shows significantly higher levels in case group compared to $2.66 \pm 0.39 \mathrm{mg} / \mathrm{dl}$ in controls. When compared to severity of hypertension SUA levels also tend to increase with increasing severity of PIH, increasing from 3.69 $\mathrm{mg} / \mathrm{dl}$ in gestational hypertension to $6.36 \mathrm{mg} / \mathrm{dl}$ in severe PE. The difference among three categories was again highly significant (table 2). It was observed that maternal complications during antepartum and postpartum period were higher once $\mathrm{SU} \geq 5 \mathrm{mg} / \mathrm{dl}$ was taken as a cut-off. Protienuria (97.7\%), coagulopathy $(13.3 \%)$, need for blood/platelet transfusion (35\%), eclampsia (13.3\%) and HELPP syndrome (6.6\%) were significantly more. (table 3). 
Complications were found to be higher, in babies born to mothers having serum uric acid more than $5 \mathrm{mg} / \mathrm{dl}$ compared to others in case group.
Birth weight was lower though not significantly. Two deaths occurred in neonatal ICU and two still-births were noted (Table 4).

Table 3. Comparison of maternal complications in cases having serum uric acid $\geq 5 \mathrm{mg} / \mathrm{dl}$ and serum uric acid $<5 \mathrm{mg} / \mathrm{dl}$.

\begin{tabular}{|c|c|c|c|c|c|}
\hline \multirow{2}{*}{ Complications } & \multicolumn{2}{|c|}{ Serum uric acid $\geq 5 \mathrm{mg} / \mathrm{dl}$ in cases $(n=45)$} & \multicolumn{2}{|c|}{ Serum uric acid $<5 \mathrm{mg} / \mathrm{dl}$ in cases $(\mathrm{n}=55)$} & \multirow{2}{*}{ P valuc } \\
\hline & Frequency & $\%$ & Frequency & $\%$ & \\
\hline Proteinuria & 44 & 97.7 & 20 & 36.3 & 0.000 \\
\hline Oliguria & 1 & 2.2 & 0 & 0.0 & 0.450 \\
\hline Blood transfusion & 8 & 17.7 & 1 & 1.8 & 0.010 \\
\hline Platelet transfusion & 8 & 17.7 & 1 & 1.8 & 0.010 \\
\hline Deranged coagulogram & 6 & 13.3 & 0 & 0.0 & 0.007 \\
\hline Abruptio placenta & 2 & 4.4 & 0 & 0.0 & 0.200 \\
\hline Eclampsia & 6 & 13.3 & 0 & 0.0 & 0.007 \\
\hline HELPP syndrome & 3 & 6.6 & 0 & 0.0 & 0.087 \\
\hline Preterm labour pain & 5 & 11.1 & 4 & 7.2 & 0.727 \\
\hline Maternal mortality & 1 & 2.2 & 0 & 0.0 & 0.450 \\
\hline
\end{tabular}

Table 4. Correlation of serum uric acid levels with foetal complications in case group.

\begin{tabular}{|c|c|c|c|c|c|}
\hline & \multicolumn{2}{|c|}{$\begin{array}{l}\text { Serum uric acid } \geq 5 \mathrm{mg} / \mathrm{dl} \text { in cases } \\
(\mathrm{n}=45)\end{array}$} & \multicolumn{2}{|c|}{$\begin{array}{l}\text { Serum uric acid }<4 \mathrm{mg} / \mathrm{dl} \text { in cases } \\
(\mathrm{n}=55)\end{array}$} & \multirow[t]{3}{*}{$P$ value } \\
\hline Birth weight $(\mathrm{kg})$ Mean \pm SD & \multicolumn{2}{|c|}{$2.365 \pm 0.697$} & \multicolumn{2}{|c|}{$2.559 \pm 0.607$} & \\
\hline Variables & Frequency & $\%$ & Frequency & $\%$ & \\
\hline Still-birth /IUD & 2 & 4.4 & 1 & 1.8 & 0.586 \\
\hline Low APGAR 1 minute & 15 & 33.3 & 7 & 12.7 & 0.013 \\
\hline Prematurity & 14 & 31.1 & 9 & 16.3 & 0.081 \\
\hline Neonatal ICU Admission & 14 & 31.1 & 8 & 14.5 & 0.046 \\
\hline Hyperbilirubi-nemia & 1 & 2.2 & 0 & 0.0 & 0.450 \\
\hline Low birth weight $(<2.5 \mathrm{~kg})$ & 24 & 53.3 & 9 & 16.3 & 0.000 \\
\hline Expired in NICU & 2 & 4.4 & 0 & 0.0 & 0.200 \\
\hline Congenital anomalies & 1 & 2.2 & 1 & 1.8 & 1.000 \\
\hline
\end{tabular}

\section{DISCUSSION}

A rising serum uric acid is now recognized as an early feature pre-eclampsia and its measurement greatly increases the accuracy of diagnosis and helps to differentiate this disorder from essential and other chronic forms of pre-existing hypertension complicating pregnancy. ${ }^{10,11}$

Serum uric acid in the normal pregnant woman has been observed to be $3.5 \pm 0.6 \mathrm{mg} / \mathrm{dl}$. In our study, the serum uric acid in controls was having a mean value of 2.66 $\mathrm{mg} / \mathrm{dl}$ compared to case group having a mean value of 5.0 $\mathrm{mg} / \mathrm{dl}$. The level rose with the increasing severity of hypertension, in consonance with the fact noted earlier in patients with histologically proven preeclampsia having the serum uric acid of $6.4 \pm 1.7 \mathrm{mg} / \mathrm{dl}$. Similar observations have been made by Samrah J. (7.3 \pm 2.7 $\mathrm{mg} / \mathrm{dl})$ and Kamath et al $(5.57 \mathrm{mg} / \mathrm{dl})$ that in preeclampsia, SUA levels rise significantly when compared to normal pregnant women. ${ }^{12,13}$ Maternal complications were noted to be higher in hypertensive pregnant women, especially so with SUA levels $\geq 5 \mathrm{mg} / \mathrm{dl}$ as compared to those with $<5 \mathrm{mg} / \mathrm{dl}$ in our study. Significant correlation exists between elevated SUA (above $5 \mathrm{mg} / \mathrm{dl}$ ) and $24 \mathrm{hrs}$ proteinuria, abruption placentae, HELPP syndrome or deranged coagulation profile etc in this study, an observation also reported by Pereira et al and Nischintha et al. ${ }^{14,15}$ Hyperuricemia in the setting of gestational hypertension is associated with adverse fetal outcome. The fetal complications are also related to serum uric acid levels in cases, with higher than $5 \mathrm{mg} / \mathrm{dl}$ SUA a lower average birth weight $(2.36 \mathrm{~kg}$ vs $2.55 \mathrm{~kg})$, chances of lower APGAR score at 1 minute(33.3 \% vs $12.7 \%$; p value $<0.001)$,prematurity $(31.1 \%$ vs $16.3 \%$, p value 0.042$)$ and fatal events like stillbirth/ IUD or death in neonatal ICU were significantly higher. Similar observations were noted for low birth-weight (Pareira et al, Kamath et al), low APGAR (Patel et al), increased NICU admission (Patel et al), showing clear association of hyperuricemia with adverse fetal outcome. ${ }^{13,14,16}$ 
The presence of hyperuricemia, therefore, identifies a population of hypertensive pregnant women at increased risk of maternal and fetal morbidity and mortality. More recent studies have also confirmed the predictive value of serum uric acid to be useful in predicting maternal/perinatal complications or adverse fetal outcomes and also to assist with management of preeclampsia. ${ }^{17}$ Serum uric acid levels of $5 \mathrm{mg} / \mathrm{dl}$ or higher indicates significantly higher risk of maternal complications, a fact that clearly emerged from this study as well and is recommended to be used for risk stratification for preventing fetomaternal complications in pregnancies complicated by hypertension.

Funding: No funding sources

Conflict of interest: None declared

Ethical approval: The study was approved by the Institutional Ethics Committee

\section{REFERENCES}

1. James PR, Nelson- Piercy. Mnagement of Hypertension before, during, and after pregnancy. Heart. 2004;90(12):1499-1504.

2. Slemons JM, Bogert LJ. The uric acid content of maternal and fetal blood. J Biol Chem. 1917;32(1):63-9.

3. Stander HJ, Cadden JF. Blood chemistry in preeclampsia and eclampsia. Am J Obstet Gynaecol. 1934;28(6):856-71.

4. Voto LS, Illia R, Darbon-Grosso HA, Imaz FU, Margulies M. Uric acid levels: a useful index of the severity of preeclamsia and perinatal prognosis. J Perinat Med. 1988;16(2):123-26.

5. Roberts JM, Bodnar LM, Lain KY, Hubel CA, Markovic N, Ness RB, et al. Uric acid is as important as proteinuria in identifying fetal risk in women with gestational hypertension. Hypertens. 2005;46(6):1263-69.

6. Bainbridge SA, Roberts JM. Uric acid as a pathogenic factor in preeclampsia. Placenta. 2008;29:67-72.

7. Katharia CL, Lafayette RA. Renal physiology of pregnancy." Advances in Chronic Kidney Dis. 2013;20(3):209-14.
8. Pennington KA, Schlitt JM, Jackson DL, Schulz LC, Schust DJ. Preeclampsia: multiple approaches for a multifactorial disease. Disease Model Mechanism. 2012;5(1):9-18.

9. Jeyabalan A, Conrad KP. Renal function during normal pregnancy and preeclampsia. Front Biosci. 2007;12(1)2425-37.

10. Dekker GA, Sibai BM. Early detection of preeclampsia. Am J Obstet Gynecol, Vol. 165, No. 1, 1991;165(1):160-72.

11. Dekker GA, Sibai BM. Low- dose aspirin in the prevention of preeclampsia and fetal growth retardation: rationale, mechanism, and clinical trials. Am J Obstet Gynecol. 1993;168(1):214-27.

12. Sarmah J. A Comparative Study of Serum Uric Acid in Gestational Hypertension, Preeclampsia and Normal Pregnancy. IOSR (IOSR-JDMS). 2015;14(8):4-6.

13. Kamath KR, Nayak SR, Shantharam M. Serum uric acid level in preeclampsia and its correlation to maternal and foetal outcome. Int $\mathbf{J}$ Biomed Res. 2014;5(01):22-4.

14. Pereira KN, Knoppka CK, Da Silva JE. Association between uric acid and severity of pre-eclampsia. Clinical Lab. 2013;60(2):309-14.

15. Nischintha S, Pallavee $P$, Ghose S. Correlation between 24-h urinary protein, spot urine protein/creatinine ratio, and serum uric acid and their association with fetomaternal outcomes in preeclamptic women. J Nat Sci Biol Med. 2014;5(2): 255-60.

16. Tejal P, Astha D. Relationship of serum uric acid level to maternal and perinatal outcome in patients with hypertensive disorders of pregnancy. Gujarat Medical J. 2014;69(2):1-3.

17. Priya AR, Jeyapriya K, Kannan NS. Accuracy of serum uric acid in predicting complications of preeclampsia . Int J Cur Res Rev. 2016;8(5):13-21.

Cite this article as: Saldanha CL, Malik S, Quraishi AU. Serum uric acid levels as a risk stratification tool in hypertensive pregnancy. Int J Reprod Contracept Obstet Gynecol 2018;7:4804-7. 